\title{
The Chloroplast Phylogenomics and Systematics of Zoysia (Poaceae)
}

\author{
Se-Hwan Cheon (D, Min-Ah Woo, Sangjin Jo, Young-Kee Kim and Ki-Joong Kim *D \\ Division of Life Sciences, Korea University, Seoul 02841, Korea; cheonsh@korea.ac.kr (S.-H.C.); \\ alskdk8445@hanmail.net (M.-A.W.); adidevil@korea.ac.kr (S.J.); gimyoung2@korea.ac.kr (Y.-K.K.) \\ * Correspondence: kimkj@korea.ac.kr; Tel.: +82-2-3290-3932
}

Citation: Cheon, S.-H.; Woo, M.-A.; Jo, S.; Kim, Y.-K.; Kim, K.-J. The Chloroplast Phylogenomics and Systematics of Zoysia (Poaceae). Plants 2021, 10, 1517. https:// doi.org/10.3390/plants10081517

Academic Editor: Khalid Meksem

Received: 8 June 2021

Accepted: 22 July 2021

Published: 24 July 2021

Publisher's Note: MDPI stays neutral with regard to jurisdictional claims in published maps and institutional affiliations.

Copyright: (C) 2021 by the authors. Licensee MDPI, Basel, Switzerland. This article is an open access article distributed under the terms and conditions of the Creative Commons Attribution (CC BY) license (https:/ / creativecommons.org/licenses/by/ $4.0 /)$.
Abstract: The genus Zoysia Willd. (Chloridoideae) is widely distributed from the temperate regions of Northeast Asia-including China, Japan, and Korea-to the tropical regions of Southeast Asia. Among these, four species-Zoysia japonica Steud., Zoysia sinica Hance, Zoysia tenuifolia Thiele, and Zoysia macrostachya Franch. \& Sav.-are naturally distributed in the Korean Peninsula. In this study, we report the complete plastome sequences of these Korean Zoysia species (NCBI acc. nos. MF953592, MF967579 MF967581). The length of Zoysia plastomes ranges from 135,854 to 135,904 bp, and the plastomes have a typical quadripartite structure, which consists of a pair of inverted repeat regions (20,962 20,966 bp) separated by a large ( $81,348 \sim 81,392 \mathrm{bp})$ and a small $(12,582 \sim 12,586 \mathrm{bp})$ single-copy region. In terms of gene order and structure, Zoysia plastomes are similar to the typical plastomes of Poaceae. The plastomes encode 110 genes, of which 76 are protein-coding genes, 30 are tRNA genes, and four are rRNA genes. Fourteen genes contain single introns and one gene has two introns. Three evolutionary hotspot spacer regions—atpB rbcL, rps16 rps3, and $r p l 32 \sim t r n L-U A G$ - were recognized among six analyzed Zoysia species. The high divergences in the atpB $r b c L$ spacer and $r p l 16 \sim r p l 3$ region are primarily due to the differences in base substitutions and indels. In contrast, the high divergence between rpl32 trnL-UAG spacers is due to a small inversion with a pair of $22 \mathrm{bp}$ stem and an 11 bp loop. Simple sequence repeats (SSRs) were identified in 59 different locations in Z. japonica, 63 in Z. sinica, 62 in Z. macrostachya, and 63 in Z. tenuifolia plastomes. Phylogenetic analysis showed that the Zoysia (Zoysiinae) forms a monophyletic group, which is sister to Sporobolus (Sporobolinae), with $100 \%$ bootstrap support. Within the Zoysia clade, the relationship of (Z. sinica, Z japonica), (Z. tenuifolia, Z. matrella), (Z. macrostachya, Z. macrantha) was suggested.

Keywords: plastome evolution; Zoysia; small inversion; rpl3-trnL-UAG spacer; simple sequence repeats

\section{Introduction}

The plant family Poaceae (grasses) consists of 768 genera and 12,074 species [1]. It is a major source of staple foods, making it the most important flowering plant family. Numerous commercial crops are developed from wild species of grasses, such as wheat (Triticum aestivum), rice (Oryza sativa), maize (Zea mays), barley, millet, oats, ryes, etc. In addition to food crops, numerous ornamental and foraging grasses are also cultivated worldwide. Grasses are dominant in agricultural landscapes and in many natural ecosystems around the world [2-5].

The old classification system of Poaceae recognized two subfamilies: Festucoideae and Panicoideae [6]. However, molecular systematic studies over the last three decades have radically changed its infrafamilial classification system. The current phylogenetic classification system of Poaceae recognizes 12 monophyletic subfamilies and 51 tribes [7-9].

The Grass Phylogeny Working Group determined the phylogeny of Poaceae using three chloroplast and three nuclear marker genes. The results revealed that Poaceae is composed of two major clades, one containing the three subfamilies Bambusoideae, Oryzoideae, and Pooideae (BOP clade), and the other containing the six subfamilies Panicoideae, Arundinoideae, Chloridoideae, Micrairoideae, Aristidoideae, and Danthonioideae 
(PACMAD clade) $[2,3,5,10]$. The relationships were later clarified to recognize three basal subfamilies-Anomochlooideae, Pharoideae, and Puelioideae [3,9].

The genus Zoysia Willd. belongs to the tribe Zoysieae of subfamily Chloridoideae. Subfamilies Chloridoideae and Danthonioideae within the PACMAD clade were found to be a sister group. The subfamily Chloridoideae comprises more than 1,420 species in approximately 140 genera $[4,11]$ and is further classified into five tribes: Centropodieae, Triraphideae, Eragrostideae, Zoysieae, and Cynodonteae [3]. The tribe Zoysieae is sister to tribe Cynodonteae within the subfamily Chloridoideae. The tribe Zoysieae is further divided into two subtribes, Zoysiinae and Sporobolinae [3,12], the former of which is represented by two genera: Zoysia and Urochondra C.E. Hubb [3].

The genus Zoysia consists of 15-18 species, some of which are widely used to create lawns in temperate climates because they can tolerate wide variations in temperature, humidity, salinity, and sunlight [13]. They are also very popular in golf courses, public lawns, burial grounds, and open slopes of mountains owing to their tendency to form dense mats and notably strong tolerances to disease and drought [14]. Several Zoysia cultivars have previously been developed through hybridization and selection, and are available commercially as sod or strip. Two popular species-Z. japonica and Z. tenuifoliaare commonly known as Korean lawn grass, Japanese lawn grass, or oriental lawn grass. Species of Zoysia are widely distributed from the temperate regions of Northeast Asiaincluding Korea, Japan, and China-to the tropical regions of Southeast Asia. Among these, four species-Z. japonica Steud., Z. sinica Hance, Z. tenuifolia Thiele, and Z. macrostachya Franch. \& Sav.-are naturally distributed in the Korean Peninsula [14].

This study determined the plastome sequences and genome structures of the aforementioned Korean Zoysia species, two of which-Z. japonica and Z. tenuifolia-are used commercially as Zoysia grasses, and Z. sinica and Z. macrostachya are known to be salttolerant species $[13,14]$. Comparative analysis was performed on these four Zoysia species and two others, i.e., Z. matrella [15] and Z. macrantha, for which plastome sequences were previously published. Additionally, phylogenetic analysis using complete gene sequences was performed to establish the relationships between Zoysia (Zoysiinae) and other lineages of Poaceae. This study provides genetic information on a useful horticultural plant and will contribute to our understanding of plastome evolution and phylogenetic relationships within the PACMAD clade.

\section{Results}

\subsection{Chloroplast Genome Structure}

NGS sequencing of $Z$. tenuifolia generated 5,385,995 total reads with an average read length of $257.3 \mathrm{bp}$. A total of 172,448 plastid reads was collected and used for plastid contig assembly. A single plastid contig covering $100 \%$ of the plastome was recovered. The complete plastomes of Zoysia species were 135,854 135,904 bp long, with an LSC region (81,348 81,392 bp), an SSC region (12,582 12,586 bp), and two IR regions (20,962 20,966 bp). The overall AT base content of the sequences was $61.6 \%$ in all four species (Table 1 ).

Table 1. The comparative feature of six Zoysia plastomes.

\begin{tabular}{|c|c|c|c|c|c|c|}
\hline Species & Zoysia japonica & Zoysia tenuifolia & Zoysia sinica & Zoysia macrostachya & Zoysia matrella* & Zoysia macrantha * \\
\hline Accession number & MF953592 & MF967580 & MF967579 & MF967581 & AP014937 & KT168390 \\
\hline Genome length (bp) & 135,854 & 135,892 & 135,872 & 135,904 & 135,810 & 135,845 \\
\hline LSC length (bp) & 81,348 & 81,376 & 81,366 & 81,392 & 81,308 & 81,352 \\
\hline SSC length (bp) & 12,582 & 12,584 & 12,582 & 12,586 & 12,583 & 12,576 \\
\hline IR length (bp) & 20,962 & 20,966 & 20,962 & 20,963 & 20,960 & 20,959 \\
\hline AT content & $61.6 \%$ & $61.6 \%$ & $61.6 \%$ & $61.6 \%$ & $61.6 \%$ & $61.6 \%$ \\
\hline Total gene contents & 110 & 110 & 110 & 110 & 110 & 110 \\
\hline
\end{tabular}

* Indicates previously published sequences $[15,16]$ available from the NCBI database.

The plastomes encoded 110 unique genes (76 protein-coding genes, 30 tRNA genes, 4 rRNA genes). Fourteen genes contained single introns and one (ycf3) had two introns 
(Figure 1 and Table 2). Unlike in typical angiosperms, the $a c c D, y c f 1$, and $y c f 2$ genes and introns in the $c l p P$ and $r p o C 1$ genes were absent.

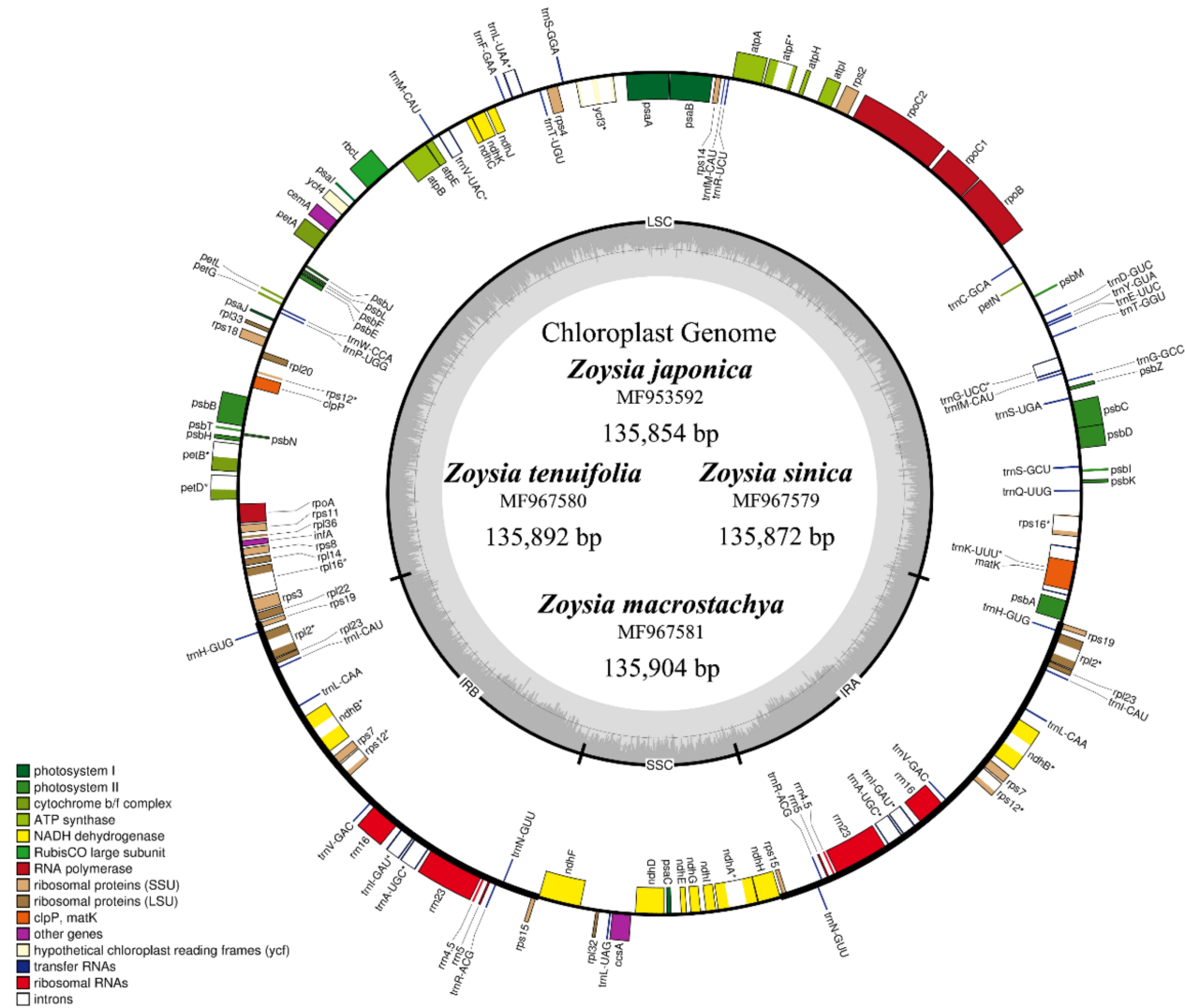

Figure 1. Genome map of the complete chloroplast sequences of Zoysia japonica and three other Zoysia species sequenced in this study. The gene order and structure among Zoysia species are the same. The gray region within the inner circle shows the GC content ratio.

Table 2. Genes in the Zoysia plastomes. Each species has 110 unique genes.

\begin{tabular}{|c|c|c|}
\hline Genes Category & Group of Genes & Name of Genes \\
\hline Self-replication & $\begin{array}{c}\text { rRNA genes } \\
\text { tRNA genes } \\
\text { Small subunit of ribosome } \\
\text { Large subunit of ribosome } \\
\text { DNA dependent RNA polymerase }\end{array}$ & $\begin{array}{c}r r n 16(\mathrm{x} 2), r r n 23(\mathrm{x} 2), r r n 4.5(\mathrm{x} 2), r r n 5(\mathrm{x} 2) \\
30 \text { trn genes }(8 \text { are in IR regions }) \\
r p s 2, r p s 3, r p s 4, r p s 7(\mathrm{x} 2), r p s 8, r p s 11, r p s 12 *(\mathrm{x} 2), r p s 14, r p s 15(\mathrm{x} 2), r p s 16^{*}, r p s 18, r p s 19(\mathrm{x} 2) \\
r p l 2 *(\mathrm{x} 2), r p l 14, r p l 16 *, r p l 20, r p l 22, r p l 23(\mathrm{x} 2), r p l 32, r p l 33, r p l 36 \\
r p o A, r p o B, r p o C 1, r p o C 2\end{array}$ \\
\hline Genes for photosynthesis & $\begin{array}{l}\text { Subunits of NADH-dehydrogenase } \\
\text { Subunits of photosystem } 1 \\
\text { Subunits of photosystem } 2 \\
\text { Subunits of cytochrome } b / f \text { complex } \\
\text { Subunits of ATP synthase } \\
\text { Large subunit of rubisco }\end{array}$ & $\begin{array}{c}n d h A^{*}, n d h B^{*}(\mathrm{x} 2), n d h C, n d h D, n d h E, n d h F, n d h G, n d h H, n d h I, n d h J, n d h K \\
p s a A, p s a B, p s a C, p s a I, p s a J \\
p s b A, p s b B, p s b C, p s b D, p s b E, p s b F, p s b H, p s b I, p s b J, p s b K, p s b L, p s b M, p s b N, p s b T, p s b Z \\
p e t A, p e t B *, p e t D^{*}, p e t G, p e t L, p e t N \\
a t p A, a t p B, a t p E, a t p F *, a t p H, \text { atpI } \\
\text { rbcL }\end{array}$ \\
\hline Other genes & $\begin{array}{c}\text { Maturase } \\
\text { Protease } \\
\text { Envelope membrane protein } \\
\text { c-type cytochrome synthesis gene } \\
\text { Translational initiation factor }\end{array}$ & $\begin{array}{c}\text { matK } \\
\operatorname{clp} P \\
\operatorname{cem} A \\
\operatorname{ccs} A \\
\inf A\end{array}$ \\
\hline Genes of unknown fu & ns Open Reading Frames (ORF) & $y c f 3 * *, y c f 4$ \\
\hline
\end{tabular}

* One or ${ }^{* *}$ two asterisk(s) beside the gene name indicate(s) that the gene contain(s) one or two intron(s), respectively. "(x2)" indicates that the gene is located on the IR regions.

The plastome maps of the four Zoysia species are shown in Figure 1. The structural organizations, gene and intron contents, gene order, and AT contents of the plastomes are similar to those of two published Zoysia plastomes (Z. matrella and Z. macrantha) and of typical poaceous plants such as Sporobolus maritima [17], O. sativa [18], and Z. mays [19]. Three 
plastome sequences from Chlorioideae (Sporobolus maritima, Cynodon dactylon, and Eragrostis minor) and one plastome sequence from Danthonioideae (Danthonia calyfornica) were selected, and detailed comparisons of their IR/SC boundaries are presented in Figure 2. Only minor length variations were observed because all species are phylogenetically closely related to each other. The $n d h F$ pseudogene at the IR/SSC boundary ranged from 19 to $29 \mathrm{bp}$ long. In addition, the $n d h H$ gene and the $n d h F$ pseudogene overlapped by $1 \mathrm{bp}$ in the plastomes of Zoysia and Sporobolus. The IR/LSC boundary is located between rps19 and rpl22 in all species. The lengths from the IR/LSC boundary to the rps19 gene ranged from 35 to $59 \mathrm{bp}$, depending on the species.

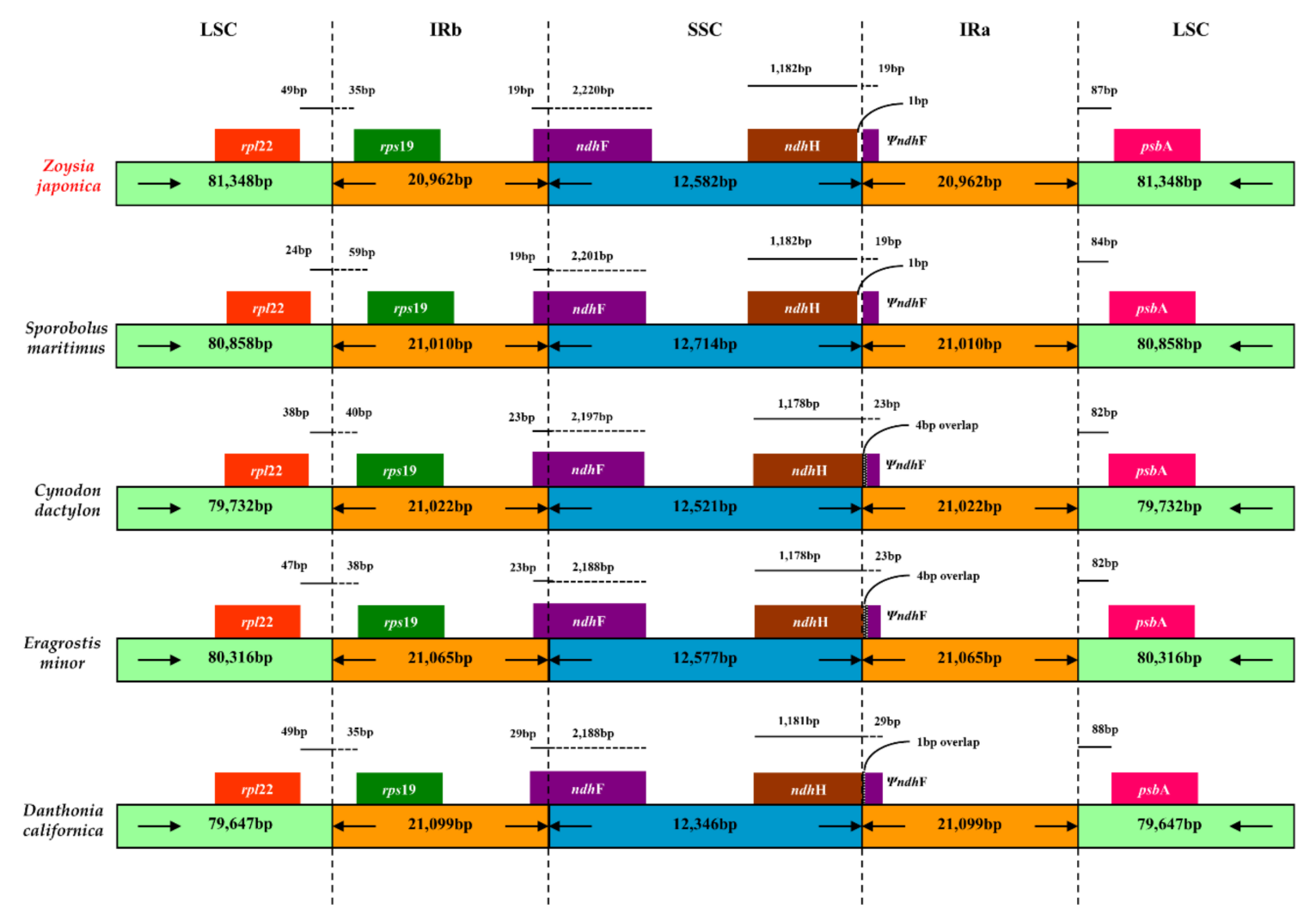

Figure 2. Comparison of the borders of the large single-copy (LSC), small single-copy (SSC), and inverted repeat (IR) regions among the plastomes of five Poaceae species. The IR regions of Zoysia species extend into the $n d h F$ gene, which is characteristic of the PACMAD clade of Poaceae. Four comparative species were selected from closely related genera to Zoysia.

\subsection{Sequence Divergence in the Zoysia Chloroplast Genomes}

The plastomes of five Zoysia species (Z. tenuifolia, Z. sinica, and Z. macrostachya from this study, and Z. matrella and Z. macrantha from published GenBank sequences) were plotted using the plastome of $Z$. japonica as a reference (Figure S1). The results showed that most of the sequences have high similarity and that the regions of low similarity between $Z$. japonica and the other Zoysia plastomes are mainly distributed in the spacer regions of SC regions. Within the LSC region, an intergenic spacer (IGS) between trnG-UCC and trnT-GGU, the $r p o C 2$ gene, the IGS from $a t p B$ to $r b c L$, and the region from the intron of $r p l 16$ to the rps3 gene showed notable differences. In the IR and SSC regions, the IGS from rpl32 to $\operatorname{trnL}-U A G$ also showed notable differences.

Six Zoysia plastomes (Z. japonica, Z. tenuifolia, Z. sinica, and Z. macrostachya from this study, and Z. matrella and Z. macrantha from published GenBank sequences) were subjected to sliding window analysis (Figure 3). Overall, the percentage of variable characters was observed to be less than $1 \%$, although relatively high values were obtained in three areas. 
For example, the two parts of the LSC region, atpB $\sim r b c L$ and $r p l 16 \sim r p l 3$ areas, and one part of the SSC region, rpl32 trnL-UAG spacer. These three parts showed more than $2 \%$ sequence divergences among the six species. The high divergences in the atpB $r b c L$ spacer and $r p l 16 \sim r p l 3$ region are primarily due to the differences in base substitutions and indels. In contrast, the high divergence between rpl32 trnL-UAG spacers is due to a small inversion (Figure 4).

Sliding window analysis of the whole chloroplast genomes of six Zoysia taxa



Figure 3. Sliding window analysis of the whole plastomes of six Zoysia species. The $x$-axis represents the midpoint position of a window, and the $y$-axis represents the nucleotide diversity of each window. Three noncoding regions (atpB rbcL, rpl16 rps3, and rpl32 trnL-UAG) show more than $2 \%$ sequence divergences among the six Zoysia species.

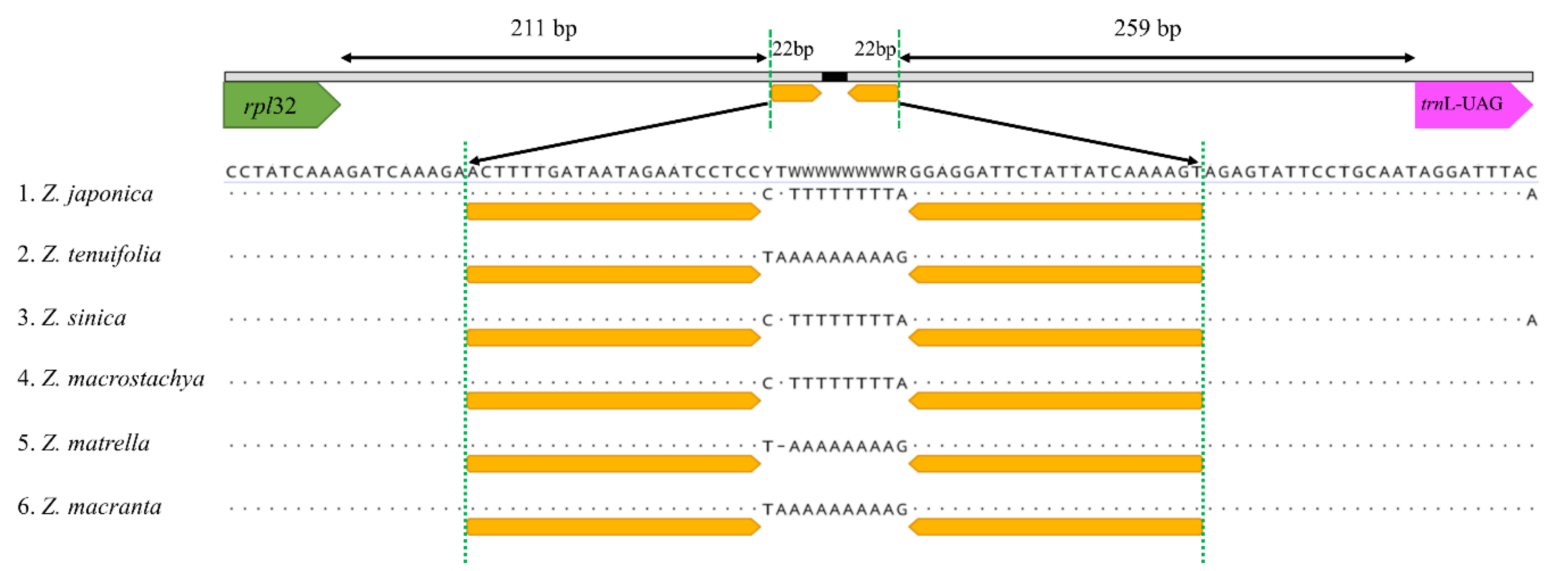

Figure 4. The sequence difference between the rpl32 and trnL-UAG genes among six Zoysia species. All six species of Zoysia have an $11 \mathrm{bp}$ long loop region, but this region has a different orientation in Z. japonica, Z. sinica, and Z. macrostachya compare to that of Z. tenuifolia, Z. matrella, and Z. macrantha. This difference is due to a small inversion at the $22 \mathrm{bp}$ long stem region (orange color). 


\subsection{Simple Sequence Repeats}

Simple sequence repeats (SSRs), also known as microsatellites, which are made up of the same nucleotide sequence or sequence units repeating over a region greater than $10 \mathrm{bp}$, were analyzed. SSRs were identified in 59 different locations in Z. japonica, 63 in Z. sinica, 62 in Z. macrostachya, and 63 in Z. tenuifolia plastomes (Table 3). The major SSR types were homopolymers (Z. japonica (50/59), Z. sinica (54/63), Z. macrostachya (53/62), and Z. tenuifolia (54/63)), whereas there were eight dipolymers and one tripolymer in the four Zoysia species. Among the homopolymers, two were composed of $\mathrm{G}$ or $\mathrm{C}$ bases and the rest comprised multiple A or T bases. Dipolymers were composed of AT, GA, TA, or TC units, whereas the single tripolymer was AAT.

Table 3. Distribution of simple sequence repeats (SSRs) among the plastomes of Zoysia japonica, Z. sinica, Z. macrostachya, and Z. tenuifolia.

\begin{tabular}{|c|c|c|c|c|c|}
\hline \multirow{2}{*}{ Unit } & \multirow{2}{*}{$\begin{array}{l}\text { Length } \\
\text { (bp) }\end{array}$} & \multirow{2}{*}{$\begin{array}{c}\text { Zoysia japonica } \\
\text { No. of SSRs }\end{array}$} & \multirow{2}{*}{$\begin{array}{c}\text { Zoysia sinica } \\
\text { No. of SSRs }\end{array}$} & \multirow{2}{*}{$\begin{array}{c}\text { Zoysia macrostachya } \\
\text { No. of SSRs }\end{array}$} & \multirow{2}{*}{$\begin{array}{c}\text { Zoysia tenuifolia } \\
\text { No. of SSRs }\end{array}$} \\
\hline & & & & & \\
\hline \multirow{8}{*}{$\mathrm{A}$} & 17 & 0 & 1 & 0 & 0 \\
\hline & 16 & 2 & 1 & 1 & 3 \\
\hline & 15 & 1 & 0 & 0 & 1 \\
\hline & 14 & 2 & 3 & 0 & 1 \\
\hline & 13 & 2 & 2 & 3 & 3 \\
\hline & 12 & 3 & 3 & 6 & 3 \\
\hline & 11 & 4 & 4 & 6 & 6 \\
\hline & 10 & 10 & 9 & 7 & 9 \\
\hline \multirow{2}{*}{$\mathrm{C}$} & 11 & 1 & 1 & 0 & 0 \\
\hline & 10 & 0 & 0 & 0 & 1 \\
\hline \multirow{2}{*}{ G } & 11 & 0 & 0 & 0 & 1 \\
\hline & 10 & 1 & 1 & 2 & 0 \\
\hline \multirow{8}{*}{$\mathrm{T}$} & 22 & 1 & 0 & 0 & 1 \\
\hline & 17 & 0 & 4 & 0 & 0 \\
\hline & 16 & 0 & 0 & 1 & 0 \\
\hline & 14 & 0 & 0 & 2 & 1 \\
\hline & 13 & 3 & 4 & 4 & 4 \\
\hline & 12 & 7 & 7 & 5 & 7 \\
\hline & 11 & 5 & 6 & 4 & 7 \\
\hline & 10 & 8 & 8 & 12 & 6 \\
\hline \multirow{2}{*}{$\mathrm{AT}$} & 12 & 1 & 1 & 1 & 1 \\
\hline & 10 & 3 & 3 & 3 & 3 \\
\hline GA & 10 & 1 & 1 & 1 & 1 \\
\hline \multirow{2}{*}{$\mathrm{TA}$} & 14 & 1 & 1 & 1 & 1 \\
\hline & 10 & 1 & 1 & 1 & 1 \\
\hline TC & 10 & 1 & 1 & 1 & 1 \\
\hline AAT & 12 & 1 & 1 & 1 & 1 \\
\hline \multicolumn{2}{|c|}{ Total } & 59 & 63 & 62 & 63 \\
\hline
\end{tabular}

\subsection{Phylogenetic Analysis}

To estimate the phylogenetic relationships in Zoysia, an ML tree was constructed from 26 complete plastomes of the subfamily Chloridoideae and one outgroup. Danthonia californica of the subfamily Danthonioideae was selected as an outgroup because the two subfamilies are sister groups [20]. The aligned length of 76 protein-coding genes and 4 rRNA genes was $61,097 \mathrm{bp}$. The ML tree was constructed with an ML optimization likelihood value of $-\ln =-142,175.088555$. The bootstrap support percentages and Bayesian posterior probability values were also given at all internal nodes (Figure 5). The tree recognized five tribes within the subfamily Chloridoideae: Centropodieae, Triraphideae, 
Eragrostideae, Zoysieae, and Cynodonteae. Two monophyletic subtribes-Zoysiinae and Sporobolinae-were identified in the tribe Zoysieae and formed a sister group. The monophyly of five tribes within the subfamily Chloridoideae, and two subtribes within the tribe Zoysieae were supported by 100 bootstrap percentages and 1.0 Bayesian posterior probability values. All six species of Zoysia formed an independent monophyletic group, as did all three species of Sporobolus. Within the genus Zoysia, three sister species pairsZ. sinica-Z. japonica, Z. tenuifolia-Z. matrella, and Z. macrostachya-Z. macrantha-were supported by $96 \%, 96 \%$, and $32 \%$ bootstrap support, respectively. The first two species pairs were monophyletic, with $94 \%$ bootstrap support. Therefore, the relationships were as follows: (Z. sinica, Z. japonica), (Z. tenuifolia, Z. matrella), (Z. macrostachya, Z. macrantha).



Figure 5. A maximum likelihood (ML) tree constructed from the plastomes of 26 species within the subfamily Chloridoideae (Poaceae) with Danthonia californica as an outgroup. The numbers at each node indicate the ML bootstrap values/Bayesian posterior probability. The ML tree was constructed from 76 protein-coding and 4 rRNA genes by RaxML. The newly sequenced species in this study are indicated in red. The short internal nodes among Zoysia species are expanded in the box at the upper left corner. 


\section{Discussion}

The longest plastome in Zoysia-belonging to Z. macrostachya-is only 82 bp longer than the shortest, Z. matrella (Table 1). This small range of difference is due to sporadic indels at some IGS regions (Figure S1). With the exception of small size differences, there are no noticeable differences among the plastomes of Zoysia (Figure 1).

Unlike the genomes of typical angiosperms [21-24], those of Zoysia lack the genes $a c c D, y c f 1$, and $y c f 2$ and introns in the $c l p P$ and $r p o C 1$ genes, which is a pattern observed in most grasses [25-27]. The loss of two introns in the $c l p P$ gene has been reported independently in different angiosperm families, including Poaceae [28-30], the IR-lacking clade of Leguminosae [31], Oleaceae (opposite-leaved Jasminum and Menodora) [32], and Onagraceae (Oenothera) [33].

Similar to the chloroplast genomes of other grasses, the IR regions in Zoysia species extend to the rps19 gene region (Figure 2). The IR regions of the Zoysia plastomes are also extended to duplicate a part of the $5^{\prime}$ end of the $n d h F$ gene, a feature that is similar to other poaceous plastomes [19,34-36]. Our results indicate that this extension of the IR into the $n d h F$ gene is characteristic of the PACMAD clade but not the BOP clade. In BOP clade species, such as those in the genera Oryza, Agrostis, Hordeum, and Bambusa, the IR is extended into a part of the $n d h H$ gene, rather than the $n d h F$ gene; this is a specific feature of BOP clade members [36-38]. Our results also show that Zoysia has all the same types of missense mutations and insertions in rpl16, rpl32, rpoC1 as Neyraudia [39].

It is well known that noncoding regions exhibit a higher level of sequence divergence than do coding regions, and in the present study, we detected relatively high sequence divergences within the noncoding regions of Zoysia plastomes (Figure 3). Three noncoding regions-the $a t p B \sim r b c L$ spacer, $r p s 16$ intron, and $r p l 21 \sim t r n L-U A G$ spacer-show more than $2 \%$ sequence differences, making them good candidates for plastome markers to differentiate Zoysia species. As described above, the $a t p B \sim r b c L$ spacer and $r p s 16$ intron/spacer regions have high divergences due to the indels and base substitutions, while the high divergence of the rpl21 trnL-UAG spacer region is primarily due to a small inversion (Figure 4). A small inversion between the $22 \mathrm{bp}$ stem region generated $11 \mathrm{bp}$ differences in the loop region. The orientation of this loop region in three species of Zoysia (Z. japonica, $Z$. sinica, and Z. macrostachya) is different from that of three other species (Z. tenuifolia, Z. matrella, and Z. macrantha). This kind of small inversion is also reported in Poaceae and other flowering plant families [24,35,40].

In addition to the genome research described earlier [15,39], there have been some systematic studies of Zoysia using molecular-based markers, such as restriction fragment length polymorphisms (RFLP) [41] and simple sequence repeats (SSR) [42,43]. In the present study, we conducted maximum likelihood analysis based on 76 protein-coding genes and 4 rRNAs using the complete chloroplast genomes and revealed that five tribes-Centropodieae, Triraphideae, Eragrostideae, Zoysieae, and Cynodonteae-are monophyletic groups in the subfamily Chloridoideae. In addition, the tribes Cynodonteae and Zoysieae are sister groups. These relationships are consistent with those established in previous studies $[3,11,12,44,45]$. Our tree indicates that the subtribe Sporobolinae is sister to the subtribe Zoysiinae (Figure 5). This relationship is also supported by other studies, even though the previous studies only used one representative species of Zoysia [44]. We used the six Zoysia species to construct the tree, but the same tree topology was generated regarding the sister group relationship of two subtribes. The subtribe Zoysiinae consists of two genera, Zoysia and Urochondria [3], but plastome sequences are not available from Urochondria. The monophyly of genus Zoysia was supported by $100 \%$ bootstrap support and 1.00 Bayesian posterior probability (BP). The three species pairs-Z. macrostachya-Z. macrantha, Z. tenuifolia-Z. matrella, and Z. japonica-Z. sinica-are all sister in our ML tree, with $32 \%(0.43 \mathrm{BP}), 96 \%(1.00 \mathrm{BP})$, and $96 \%$ (1.00 BP) bootstrap support, respectively. In addition, the monophyly of the Z. tenuifolia-Z. matrella and Z. japonica-Z. sinica pairs is also supported by $94 \%$ (1.00 BP) bootstrap support. These results are different from those of a previous systematic study [43], in which Z. matrella and Z. japonica form a monophyly with 
$68.2 \%$ support, and Z. tenuifolia is sister to this clade with $100 \%$ support. Accordingly, we will need to analyze more complete plastomes to resolve these differences. Whole-genome sequences will provide more convincing evidence for the relationships among the species of Zoysia that show low levels of plastome sequence divergence.

\section{Materials and Methods}

\subsection{Plant Materials, DNA Extraction, and Sequencing}

The leaves of Zoysia tenuifolia were collected from a greenhouse at the Korea University, where the authors grow plants originally collected from natural habitats in Korea. The leaves of Z. japonica, Z. sinica, and Z. macrostachya were collected directly from plants growing in natural habitats in Korea. Voucher specimens of each species were deposited in the Korea University Herbarium (Z. tenuifolia: KUS2017-0002, Z. japonica: KUS2013-0161, Z. sinica: KUS2010-1956, and Z. macrostachya: KUS2013-0307). Fresh leaves were ground into powder in liquid nitrogen, and total genomic DNAs were extracted using the CTAB method [46]. The DNA was purified using CsCl/EtBr gradient ultra-centrifugation [47], then further purified by dialysis [48]. The genomic and chloroplast DNAs were deposited into the Plant DNA Bank in Korea (PDBK) under the accession numbers PDBK2017-0002, PDBK2013-0161, PDBK2010-1956, and PDBK2013-0307.

Approximately $100 \mathrm{ng}$ of Z. tenuifolia DNA was used for NGS sequencing using an Ion Torrent PGM ${ }^{\mathrm{TM}}$ sequencer (Thermo Fisher Scientific, Waltham, MA, USA). The library was fabricated as pair ends through an Ion Plus fragment library kit (Thermo Fisher Scientific, Waltham, MA, USA). The target library size was 300 base reads, and fragmentation was performed using a Bioruptor ${ }^{\circledR}$ UCD-600 NGS Sonication system (Diagenode, Denville, NJ, USA). The library size selection was performed using E-gel ${ }^{\circledR}$ size select ${ }^{\mathrm{TM}} 2 \%$ Agarose gel (Thermo Fisher), and Bioanalyzer ${ }^{\circledR}$ instrument analysis; 2100 Bioanalyzer (Agilent Technologies Inc., Santa Clara, CA, USA) was used for library normalization/quantification. Ion PGM ${ }^{\mathrm{TM}}$ Sequencing $400 \mathrm{Kit}$ and Ion $318^{\mathrm{TM}}$ Chip v2 (Thermo Fisher Scientific) were used for sequencing. The raw sequenced NGS data were uploaded to the National Center for Biotechnology Information (NCBI) Sequence Read Archive (SRA; acc. No. PRJNA548200).

NGS sequencing was performed on Z. tenuifolia and PCR sequencing was performed on the other three-Z. japonica, Z. sinica, and Z. macrostachya. Purified total DNAs of Z. japonica, Z. sinica, and Z. macrostachya were amplified using a series of primer sets developed from the Z. tenuifolia, Z. matrella, and Panicum virgatum [49] plastomes. The primers used to sequence the three Zoysia species are listed in Tables S2-S4. Continuous sequencing was performed on PCR products using primer walking for whole-plastome sequencing [50]. The PCR products were purified using a MEGAquick-spin Total Fragment DNA purification Kit (iNtRON Biotechnology, Seongnam, Korea), and the cleaned products were sequenced in both directions using an ABI 3730xl DNA analyzer (Thermo Fisher Scientific, Waltham, MA, USA).

\subsection{Chloroplast Genome Assembly and Annotation}

All of the generated raw reads were trimmed using a basic application in Geneious version 8.1.9 [51] with an error probability limit $=0.05$. We assembled the trimmed raw reads with $Z$. matrella as the reference. After mapping the reads to the plastome of $Z$. matrella, low-coverage regions were removed. Trimmed reads were then mapped again to the obtained contigs to form longer contigs. After removing the low-coverage regions again, the contigs with overlapping regions were merged to create larger contigs. This process was repeated for the entire plastome sequence.

Initial annotations of the four chloroplast genomes were generated by DOGMA [52]. To complement the out-of-date DOGMA database, these annotations were manually edited by comparing them to published Poaceae chloroplast genomes (Table S1) using BLAST. When a discrepancy was found, the annotation was confirmed using the ORF finder program from the National Center for Biotechnology Information (NCBI) and tRNAscan- 
SE 2.0 [53] for the corresponding parts. Circular chloroplast genome maps were generated using OrganellarGenomeDraw [54].

\subsection{Sequence Analysis}

Two previously published Zoysia plastome sequences-Z. matrella (GenBank Acc. No.: AP014937) and Z. macrantha (GenBank acc. No. KT168390)—were included in our sequence comparison analysis. To plot sequence divergence among the Zoysia chloroplast genomes, we used mVISTA [55] with default parameter settings. The plastome sequences were aligned using MAFFT [56] and sliding window analysis was performed using DnaSP v6 [57] on the aligned sequence. The window length was set to $300 \mathrm{bp}$, with a $100 \mathrm{bp}$ step size. Simple sequence repeats (SSRs) were analyzed using the Phobos tandem repeat tool [58] in Geneious v8.1.9 [51] with default parameters.

\subsection{Phylogenetic Analysis}

We constructed the phylogenetic tree using whole plastid sequences from all available plastome sequences of subfamily Chloridoideae and a member of subfamily Danthenoideae, Danthonia californica. A total of 27 complete chloroplast genomes were used for phylogeny construction (Table S1). The 76 protein-coding gene and four rRNA gene sequences were extracted from each plastome and then aligned using MUSCLE v.3.8.425 [59] with default parameters. We selected the GTR base substitution model based on the Akaike Information Criterion (AIC) through the PAUP modeltest [60]. Maximum likelihood (ML) analysis was conducted using RAxML-HPC BlackBox v.8.2.10 [61] in CIPRES Science Gateway v3.3.3 [62]. Default parameters were used, and the ML bootstrap support values of each internal node were evaluated using 1000 replications. Bayesian posterior probability was conducted using MrBayes v3.2.6 [63] plugin tool in Geneious v8.1.9 [51]. The substitution model was GTR and the rate variation was set to equal. The MCMC chain length was $1,000,000$ and the subsampling frequency was 100 . The heated chain was set to 4 , burn-in length to 2500 , and heated chain temperature to 0.2 .

\section{Conclusions}

In this study, we identified four new plastome sequences from species of Zoysia and described the evolutionary features of these genomes. There was no significant difference among these plastomes. In addition, we examined phylogenetic relationships using all the chloroplast genes of six Zoysia species. The genus Zoysia formed a monophyletic group and the tribe Zoysieae consisted of the subtribes Sporobolinae and Zoysiinae. However, analysis of a larger number of plastome sequences will be needed to more accurately determine the phylogenetic relationships among Zoysia species.

Supplementary Materials: Supplementary Materials can be found at https://www.mdpi.com/ article/10.3390/plants10081517/s1. Figure S1: mVISTA identity plot comparing Zoysia plastomes. The $Z$. japonica plastome was used as a reference. The vertical scale indicates the percentage identity, ranging from $50 \%$ to $100 \%$. White, blue, and pink regions indicate unmatched, coding, and noncoding regions, respectively, Table S1: The GenBank accession number used in this study, Table S2: The Primer list of sequencing of Zoysia japonica, Table S3: The Primer list of sequencing of Zoysia macrostachya, Table S4: The Primer list of sequencing of Zoysia sinica.

Author Contributions: Conceptualization, K.-J.K.; formal analysis, S.-H.C. and M.-A.W.; investigation, M.-A.W., S.J. and Y.-K.K.; resources, K.-J.K.; data curation, S.-H.C. and K.-J.K.; writing-original draft preparation, S.-H.C. and M.-A.W.; writing-review and editing, K.-J.K.; supervision, K.-J.K. All authors have read and agreed to the published version of the manuscript.

Funding: This work was supported by the National Research Foundation of Korea (NRF) under grant no. NRF-2021R1A2C1013731 and 2020 Korea University Research Fund to o K.-J.K. 
Data Availability Statement: The chloroplast sequence data presented in this study are available in GenBank (NCBI acc. nos. MF953592, MF967579 MF967581). The raw sequenced NGS data were uploaded to the National Center for Biotechnology Information (NCBI) Sequence Read Archive (SRA; acc. No. PRJNA548200).

Acknowledgments: We would like to thank the curator of the Korea University Herbarium (KUS) for preparing the voucher specimen. The genomic and chloroplast DNAs are deposited in the Plant DNA Bank in Korea (PDBK). We also thank Noah Last for the English editing of the manuscript.

Conflicts of Interest: The authors declare no competing interests and are independently responsible for the content and writing of the paper.

$\begin{array}{ll}\text { Abbreviations } \\ \text { LSC } & \text { Large Single Copy } \\ \text { SSC } & \text { Small Single Copy } \\ \text { IR } & \text { Inverted Repeat } \\ \text { SSR } & \text { Simple Sequence Repeat } \\ \text { ML } & \text { Maximum Likelihood }\end{array}$

\section{References}

1. Soreng, R.; Davidse, G.; Peterson, P.; Zuloaga, F.; Judziewicz, E.; Filgueiras, T.; Morrone, O.; Romaschenko, K. A WorldWide Phylogenetic Classification of Poaceae (Gramineae). Available online: http:/ /legacy.tropicos.org/projectwebportal.aspx? pagename $=$ ClassificationNWG\&projectid=10 (accessed on 20 September 2020).

2. Clayton, W.D.; Renvoize, S.A. Genera graminum. Grasses of the world. Kew Bull. Addit. Ser. 1986, 13, 1-389.

3. Soreng, R.J.; Peterson, P.M.; Romaschenko, K.; Davidse, G.; Zuloaga, F.O.; Judziewicz, E.J.; Filgueiras, T.S.; Davis, J.I.; Morrone, O. A worldwide phylogenetic classification of the Poaceae (Gramineae). J. Syst. Evol. 2015, 53, 117-137. [CrossRef]

4. Watson, L.; Dallwitz, M.J. The Grass Genera of the World; CAB international: Wallingford, UK, 1992.

5. Wu, Z.-Q.; Ge, S. The phylogeny of the BEP clade in grasses revisited: Evidence from the whole-genome sequences of chloroplasts. Mol. Phylogenet. Evol. 2012, 62, 573-578. [CrossRef]

6. $\quad$ Brown, R. Gramineae. In A Voyage to Terra Australis; Flinders, M., Ed.; W. Bulmer \& Company: London, UK, 1814; pp. 5583-5803.

7. Bouchenak-Khelladi, Y.; Salamin, N.; Savolainen, V.; Forest, F.; van der Bank, M.; Chase, M.W.; Hodkinson, T.R. Large multi-gene phylogenetic trees of the grasses (Poaceae): Progress towards complete tribal and generic level sampling. Mol. Phylogenet. Evol. 2008, 47, 488-505. [CrossRef] [PubMed]

8. Bouchenak-Khelladi, Y.; Muasya, A.M.; Linder, H.P. A revised evolutionary history of Poales: Origins and diversification. Bot. J. Linn. Soc. 2014, 175, 4-16. [CrossRef]

9. Grass Phylogeny Working Group II. New grass phylogeny resolves deep evolutionary relationships and discovers C4 origins. New Phytol. 2012, 193, 304-312. [CrossRef] [PubMed]

10. Grass Phylogeny Working Group; Barker, N.P.; Clark, L.G.; Davis, J.I.; Duvall, M.R.; Guala, G.F.; Hsiao, C.; Kellogg, E.A.; Linder, H.P.; Mason-Gamer, R.J. Phylogeny and subfamilial classification of the grasses (Poaceae). Ann. Mo. Bot. Gard. 2001, 88, 373-457.

11. Peterson, P.M.; Romaschenko, K.; Johnson, G. A classification of the Chloridoideae (Poaceae) based on multi-gene phylogenetic trees. Mol. Phylogenet. Evol. 2010, 55, 580-598. [CrossRef]

12. Peterson, P.M.; Romaschenko, K.; Arrieta, Y.H.; Saarela, J.M. A molecular phylogeny and new subgeneric classification of Sporobolus (Poaceae: Chloridoideae: Sporobolinae). Taxon 2014, 63, 1212-1243. [CrossRef]

13. Casler, M.D. Turfgrass Biology, Genetics, and Breeding; John Wiley \& Sons: Hoboken, NJ, USA, 2003.

14. Lee, T.B. Coloured Flora of Korea; Hayangmunsa: Seoul, Korea, 2003.

15. Tanaka, H.; Hirakawa, H.; Muguerza, M.; Hashiguchi, M.; Tabata, S.; Akashi, R.; Sato, S. The Complete Chloroplast Genome Sequence of Zoysia matrella (L.) Merr. Crop. Sci. 2016, 56, 1206-1212. [CrossRef]

16. Hajek, T.J., III. Characterization of Microstructural Mutation Events in Plastomes of Chloridoid Grasses (Chloridoideae; Poaceae). Master's Dissertation, Northern Illinois University, De Kalb, IL, USA, 2016.

17. Rousseau-Gueutin, M.; Bellot, S.; Martin, G.E.; Boutte, J.; Chelaifa, H.; Lima, O.; Michon-Coudouel, S.; Naquin, D.; Salmon, A.; Ainouche, K.; et al. The chloroplast genome of the hexaploid Spartina maritima (Poaceae, Chloridoideae): Comparative analyses and molecular dating. Mol. Phylogenet. Evol. 2015, 93, 5-16. [CrossRef]

18. Wambugu, P.W.; Brozynska, M.; Furtado, A.; Waters, D.L.; Henry, R.J. Relationships of wild and domesticated rices (Oryza AA genome species) based upon whole chloroplast genome sequences. Sci. Rep. 2015, 5, 13957. [CrossRef]

19. Maier, R.M.; Neckermann, K.; Igloi, G.L.; Kössel, H. Complete sequence of the maize chloroplast genome: Gene content, hotspots of divergence and fine tuning of genetic information by transcript editing. J. Mol. Biol. 1995, 251, 614-628. [CrossRef]

20. Cotton, J.L.; Wysocki, W.P.; Clark, L.G.; Kelchner, S.A.; Pires, J.C.; Edger, P.P.; Mayfield-Jones, D.; Duvall, M.R. Resolving deep relationships of PACMAD grasses: A phylogenomic approach. BMC Plant Biol. 2015, 15, 178. [CrossRef] 
21. Cheon, S.-H.; Jo, S.; Kim, H.-W.; Kim, Y.-K.; Sohn, J.-Y.; Kim, K.-J. The complete plastome sequence of Durian, Durio zibethinus L. (Malvaceae). Mitochondrial DNA B Resour. 2017, 2, 763-764. [CrossRef]

22. Jo, S.; Kim, H.-W.; Kim, Y.-K.; Cheon, S.-H.; Kim, K.-J. Complete plastome sequence of Averrhoa carambola L. (Oxalidaceae). Mitochondrial DNA B Resour. 2016, 1, 609-611. [CrossRef] [PubMed]

23. Kim, Y.-K.; Kwak, M.H.; Chung, M.G.; Kim, H.-W.; Jo, S.; Sohn, J.-Y.; Cheon, S.-H.; Kim, K.-J. The complete plastome sequence of the endangered orchid Oberonia japonica (Orchidaceae). Mitochondrial DNA B Resour. 2017, 2, 711-713. [CrossRef] [PubMed]

24. Yi, D.-K.; Kim, K.-J. Complete chloroplast genome sequences of important oilseed crop Sesamum indicum L. PLoS ONE 2012, 7, e35872. [CrossRef] [PubMed]

25. Guisinger, M.M.; Chumley, T.W.; Kuehl, J.V.; Boore, J.L.; Jansen, R.K. Implications of the plastid genome sequence of Typha (Typhaceae, Poales) for understanding genome evolution in Poaceae. J. Mol. Evol. 2010, 70, 149-166. [CrossRef] [PubMed]

26. Harris, M.E.; Meyer, G.; Vandergon, T.; Vandergon, V.O. Loss of the acetyl-CoA carboxylase (accD) gene in Poales. Plant Mol. Biol. Rep. 2013, 31, 21-31. [CrossRef]

27. Wysocki, W.P.; Burke, S.V.; Swingley, W.D.; Duvall, M.R. The First Complete Plastid Genome from Joinvilleaceae (J. ascendens; Poales) Shows Unique and Unpredicted Rearrangements. PLoS ONE 2016, 11, e0163218.

28. Hiratsuka, J.; Shimada, H.; Whittier, R.; Ishibashi, T.; Sakamoto, M.; Mori, M.; Kondo, C.; Honji, Y.; Sun, C.-R.; Meng, B.-Y. The complete sequence of the rice (Oryza sativa) chloroplast genome: Intermolecular recombination between distinct tRNA genes accounts for a major plastid DNA inversion during the evolution of the cereals. Mol. Gen. Genet. 1989, 217, 185-194. [CrossRef]

29. Huang, Y.-Y.; Cho, S.-T.; Haryono, M.; Kuo, C.-H. Complete chloroplast genome sequence of common bermudagrass (Cynodon dactylon (L.) Pers.) and comparative analysis within the family Poaceae. PLoS ONE 2017, 12, e0179055.

30. Ogihara, Y.; Isono, K.; Kojima, T.; Endo, A.; Hanaoka, M.; Shiina, T.; Terachi, T.; Utsugi, S.; Murata, M.; Mori, N. Structural features of a wheat plastome as revealed by complete sequencing of chloroplast DNA. Mol. Genet. Genom. 2002, 266, 740-746. [CrossRef]

31. Jansen, R.K.; Wojciechowski, M.F.; Sanniyasi, E.; Lee, S.-B.; Daniell, H. Complete plastid genome sequence of the chickpea (Cicer arietinum) and the phylogenetic distribution of rps12 and clpP intron losses among legumes (Leguminosae). Mol. Phylogenet. Evol. 2008, 48, 1204-1217. [CrossRef]

32. Lee, H.-L.; Jansen, R.K.; Chumley, T.W.; Kim, K.-J. Gene relocations within chloroplast genomes of Jasminum and Menodora (Oleaceae) are due to multiple, overlapping inversions. Mol. Biol. Evol. 2007, 24, 1161-1180. [CrossRef]

33. Hupfer, H.; Swiatek, M.; Hornung, S.; Herrmann, R.; Maier, R.; Chiu, W.-L.; Sears, B. Complete nucleotide sequence of the Oenothera elata plastid chromosome, representing plastome I of the five distinguishable Euoenothera plastomes. Mol. Gen. Genet. 2000, 263, 581-585. [CrossRef]

34. Asano, T.; Tsudzuki, T.; Takahashi, S.; Shimada, H.; Kadowaki, K.-i. Complete nucleotide sequence of the sugarcane (Saccharum officinarum) chloroplast genome: A comparative analysis of four monocot chloroplast genomes. DNA Res. 2004, 11, 93-99. [CrossRef]

35. Leseberg, C.H.; Duvall, M.R. The complete chloroplast genome of Coix lacryma-jobi and a comparative molecular evolutionary analysis of plastomes in cereals. J. Mol. Evol. 2009, 69, 311-318. [CrossRef]

36. Saski, C.; Lee, S.-B.; Fjellheim, S.; Guda, C.; Jansen, R.K.; Luo, H.; Tomkins, J.; Rognli, O.A.; Daniell, H.; Clarke, J.L. Complete chloroplast genome sequences of Hordeum vulgare, Sorghum bicolor and Agrostis stolonifera, and comparative analyses with other grass genomes. Theor. Appl. Genet. 2007, 115, 571-590. [CrossRef] [PubMed]

37. Tang, J.; Xia, H.; Cao, M.; Zhang, X.; Zeng, W.; Hu, S.; Tong, W.; Wang, J.; Wang, J.; Yu, J. A comparison of rice chloroplast genomes. Plant Physiol. 2004, 135, 412-420. [CrossRef]

38. Wu, F.-H.; Kan, D.-P.; Lee, S.-B.; Daniell, H.; Lee, Y.-W.; Lin, C.-C.; Lin, N.-S.; Lin, C.-S. Complete nucleotide sequence of Dendrocalamus latiflorus and Bambusa oldhamii chloroplast genomes. Tree Physiol. 2009, 29, 847-856. [CrossRef]

39. Tanaka, H.; Hirakawa, H.; Kosugi, S.; Nakayama, S.; Ono, A.; Watanabe, A.; Hashiguchi, M.; Gondo, T.; Ishigaki, G.; Muguerza, M. Sequencing and comparative analyses of the genomes of zoysiagrasses. DNA Res. 2016, 23, 171-180. [CrossRef] [PubMed]

40. Kim, K.-J.; Lee, H.-L. Widespread occurrence of small inversions in the chloroplast genomes of land plants. Mol. Cells 2005, 19, 104-113.

41. Yaneshita, M.; Nagasawa, R.; Engelke, M.C.; Sasakuma, T. Genetic variation and interspecific hybridization among natural populations of zoysiagrasses detected by RFLP analyses of chloroplast and nuclear DNA. Genes Genet. Syst. 1997, 72, 173-179. [CrossRef]

42. Hashiguchi, M.; Tsuruta, S.; Matsuo, T.; Ebina, M.; Kobayashi, M.; Akamine, H.; Akashi, R. Analysis of genetic resource in Zoysia spp, 2: Evaluation of genetic diversity in zoysiagrass indigenous to southwest islands of Japan based on simple sequence repeat markers. Jpn. J. Grassl. Sci. 2007, 53, 133-137.

43. Tsuruta, S.I.; Hosaka, F.; Otabara, T.; Hashiguchi, M.; Yamamoto, T.; Akashi, R. Genetic diversity of chloroplast DNA in Zoysia and other warm-season turfgrasses. Grassl. Sci. 2008, 54, 151-159. [CrossRef]

44. Saarela, J.M.; Burke, S.V.; Wysocki, W.P.; Barrett, M.D.; Clark, L.G.; Craine, J.M.; Peterson, P.M.; Soreng, R.J.; Vorontsova, M.S.; Duvall, M.R. A 250 plastome phylogeny of the grass family (Poaceae): Topological support under different data partitions. Peer] 2018, 6, e4299. [CrossRef] [PubMed]

45. Soreng, R.J.; Peterson, P.M.; Romaschenko, K.; Davidse, G.; Teisher, J.K.; Clark, L.G.; Barberá, P.; Gillespie, L.J.; Zuloaga, F.O. A worldwide phylogenetic classification of the Poaceae (Gramineae) II: An update and a comparison of two 2015 classifications. J. Syst. Evol. 2017, 55, 259-290. [CrossRef]

46. Doyle, J.; Doyle, J. A rapid DNA isolation procedure for small quantities of fresh leaf tissue. Phytochem. Bull. 1987, 19, 11-15. 
47. Sambrook, J.; Fritsch, E.; Maniatis, T. Molecular Cloning: A Laboratory Manual; Cold Spring Laboratory Press: New York, NY, USA, 1989.

48. Palmer, J.D. Isolation and structural analysis of chloroplast DNA. Methods Enzymol. 1986, 118, 167-186.

49. Young, H.A.; Lanzatella, C.L.; Sarath, G.; Tobias, C.M. Chloroplast genome variation in upland and lowland switchgrass. PLoS ONE 2011, 6, e23980. [CrossRef]

50. Jansen, R.K.; Raubeson, L.A.; Boore, J.L.; Chumley, T.W.; Haberle, R.C.; Wyman, S.K.; Alverson, A.J.; Peery, R.; Herman, S.J.; Fourcade, H.M. Methods for obtaining and analyzing whole chloroplast genome sequences. Methods Enzymol. 2005, 395, 348-384.

51. Kearse, M.; Moir, R.; Wilson, A.; Stones-Havas, S.; Cheung, M.; Sturrock, S.; Buxton, S.; Cooper, A.; Markowitz, S.; Duran, C. Geneious Basic: An integrated and extendable desktop software platform for the organization and analysis of sequence data. Bioinformatics 2012, 28, 1647-1649. [CrossRef] [PubMed]

52. Wyman, S.K.; Jansen, R.K.; Boore, J.L. Automatic annotation of organellar genomes with DOGMA. Bioinformatics 2004, 20, 3252-3255. [CrossRef] [PubMed]

53. Lowe, T.M.; Chan, P.P. tRNAscan-SE On-line: Integrating search and context for analysis of transfer RNA genes. Nucleic Acids Res. 2016, 44, W54-W57. [CrossRef] [PubMed]

54. Lohse, M.; Drechsel, O.; Kahlau, S.; Bock, R. OrganellarGenomeDRAW-A suite of tools for generating physical maps of plastid and mitochondrial genomes and visualizing expression data sets. Nucleic Acids Res. 2013, 41, W575-W581. [CrossRef]

55. Frazer, K.A.; Pachter, L.; Poliakov, A.; Rubin, E.M.; Dubchak, I. VISTA: Computational tools for comparative genomics. Nucleic Acids Res. 2004, 32, W273-W279. [CrossRef]

56. Katoh, K.; Standley, D.M. MAFFT multiple sequence alignment software version 7: Improvements in performance and usability. Mol. Biol. Evol. 2013, 30, 772-780. [CrossRef]

57. Rozas, J.; Ferrer-Mata, A.; Sánchez-Del Barrio, J.C.; Guirao-Rico, S.; Librado, P.; Ramos-Onsins, S.E.; Sánchez-Gracia, A. DnaSP 6 : DNA Sequence Polymorphism Analysis of Large Data Sets. Mol. Biol. Evol. 2017, 34, 3299-3302. [CrossRef] [PubMed]

58. Mayer, C.; Leese, F.; Tollrian, R. Genome-wide analysis of tandem repeats in Daphnia pulex-a comparative approach. BMC Genom. 2010, 11, 277. [CrossRef]

59. Edgar, R.C. MUSCLE: Multiple sequence alignment with high accuracy and high throughput. Nucleic Acids Res. 2004, 32, 1792-1797. [CrossRef] [PubMed]

60. Posada, D.; Crandall, K.A. Modeltest: Testing the model of DNA substitution. Bioinformatics 1998, 14, 817-818. [CrossRef]

61. Stamatakis, A. RAxML version 8: A tool for phylogenetic analysis and post-analysis of large phylogenies. Bioinformatics 2014, 30, 1312-1313. [CrossRef] [PubMed]

62. Miller, M.A.; Pfeiffer, W.; Schwartz, T. Creating the CIPRES Science Gateway for inference of large phylogenetic trees. In Proceedings of the Gateway Computing Environments Workshop (GCE), New Orleans, LA, USA, 14 November 2010; IEEE: Piscataway, NJ, USA; 2010.

63. Huelsenbeck, J.P.; Ronquist, F. MRBAYES: Bayesian inference of phylogenetic trees. Bioinformatics 2001, 17, 754-755. [CrossRef] [PubMed] 